\title{
STRATEGIA ROZWOJU JAKO INSTRUMENT \\ ZARZĄDZANIA ROZWOJEM REGIONALNYM \\ I LOKALNYM (NA PRZYKLADZIE WOJEWÓDZTWA PODLASKIEGO)
}

\section{Wstęp}

Nauka o zarządzaniu, w tradycyjnych definicjach, odnosi się do sektora prywatnego. W ostatnich latach obserwowany jest jednak wzrost zainteresowania zarządzaniem w sektorze publicznym. $\mathrm{W}$ gospodarce znaczna rola $\mathrm{w}$ pobudzaniu i kształtowaniu rozwoju gospodarczego przypada władzom regionalnym i lokalnym. Szanse rozwojowe regionów zwiększają się, jeśli prowadzą one aktywną politykę rozwoju regionalnego, charakteryzują się wysoką jakością zarządzania oraz tworzą długofalową strategię rozwoju społecznogospodarczego. Strategia rozwoju regionu formułuje cele i priorytety, a także narzędzia realizacji tych celów oraz pożądane tendencje zmian, które należy promować w celu uzyskania określonego efektu. Celem artykułu jest przedstawienie strategii, jako kluczowego dokumentu programowego, określającego zasady i kierunki długofalowej koncepcji zarządzania rozwojem regionu przy współpracy wszystkich jego środowisk.

\section{Istota strategii rozwoju regionalnego i lokalnego}

We współczesnym świecie region nie rywalizuje tylko i wyłącznie $\mathrm{z}$ innymi regionami danego państwa. W wyniku globalizacji region bierze udział $\mathrm{w}$ konkurencji światowej. Procesy rozwojowe regionu są bardzo złożone i wymagają wielu działań. Ma to związek z podmiotami istniejącymi wewnątrz regionu, ich zróżnicowanymi celami i potrzebami. Dlatego tak ważne jest planowanie. Fizycznym efektem planowania są dokumenty planistyczne, takie jak strategie. Planowanie jest szczególnie ważne w regionach słabiej rozwiniętych, które potrzebują wielu starań, by zniwelować dysproporcje w rozwoju. Planowanie jest również potrzebne, żeby analizować mocne strony dla ich jak najlepszego

\footnotetext{
* Doktorantka, Wydział Ekonomii i Zarządzania, Uniwersytet w Białymstoku.
} 
wykorzystania oraz eliminować słabe strony. Planowanie przejawia się przez tworzenie strategii, która pełni funkcję drogowskazu w realizacji przedsięwzięć podmiotów lokalnych. W związku z szerzącą się globalizacją oraz konkurencją regionów, zmieniające warunki wewnętrzne i zewnętrzne wymuszają ciągłą analizę strategii oraz jej aktualizację i poszerzanie.

Strategia umożliwia dalekosiężne spojrzenie na rozwój regionu, tak by w przyszłości był on bardziej konkurencyjny, a także pozbył się zagrożeń. Inną zaletą stosowania strategii w zarządzaniu regionalnym jest porozumienie co do rezultatów planowania. W tworzeniu strategii bierze udział wiele podmiotów, także podmioty prywatne. Strategia jest czytelnym przedstawieniem celów regionu, które zostały ustalone wspólnie przez wszystkie zainteresowane podmioty. System gospodarki regionalnej i lokalnej jest bardzo złożony. Liczba podmiotów, ich motywacji oraz siła ich wpływu może być bardzo różna. Dlatego ustalenie wspólnych celów, zawartych w strategii, poprzez wypracowanie konsensusu jest bardzo ważne dla przyszłego zrównoważonego rozwoju regionalnego i lokalnego.

Słowo „strategia” pochodzi z języka greckiego i oznacza przygotowanie oraz prowadzenie wojny lub poszczególnych bitew ${ }^{1}$. Strategia jest planowaniem, a od planowania zaczyna się proces zarządzania każdą jednostką. W wyniku dobrych rezultatów wykorzystania strategii $\mathrm{w}$ zarządzaniu organizacjami, wdrożono instrument strategii do zarządzania regionalnego i lokalnego w taki sposób, że z czasem stała się kluczowym instrumentem zarządzania rozwojem regionalnym i lokalnym. Strategia ma za zadanie wyznaczenie wspólnych celów oraz środków ich realizacji, jakimi dysponuje region. Największymi problemami z jakimi może spotkać się proces wdrażania strategii są niestety brak środków finansowych oraz nieporozumienia $\mathrm{w}$ interpretacji strategii i jej zgodności z innymi dokumentami. Przypadków tych unika się poprzez ścisłą współpracę podmiotów oraz pilnowanie spójności danych dokumentów. Strategia rozwoju regionalnego i lokalnego powinna zawierać także problemy mieszkańców regionu oraz sposób alokacji zasobów. Władze samorządu powinny interesować się problemami mieszkańców i wwyniku tego zainteresowania powstawać powinna strategia. Władze regionalne powinny mieć na celu poprawę warunków życia mieszkańców, a także rozwój w oparciu o potencjał gospodarczy regionu. Strategia powinna uwzględniać również inne czynniki, takie

${ }^{1}$ K. Wlaźlak, Rozwój regionalny jako zadanie administracji publicznej, Wolters Kluwer, Warszawa 2010, s. 259. 
jak czynniki kulturowe, system prawny, realia polityczne, aspiracje rządzących, położenie geograficzne oraz możliwości ekonomiczne ${ }^{2}$. Co więcej, ważne jest zwiększanie świadomości mieszkańców regionu w zakresie istnienia strategii oraz możliwości ingerencji ich samych $\mathrm{w}$ tworzenie tego dokumentu.

W związku z tak dużą ilością czynników wpływających na treść strategii, powinna być ona tworzona w ramach pewnych schematów. W. Kosiedowski ${ }^{3}$ wyróżnia dwie koncepcje tworzenia strategii rozwoju regionalnego i lokalnego. Pierwsza z nich polega na analizie gotowych strategii innych województw, czy gmin oraz adaptacji najlepszych rozwiązań, przy uwzględnieniu różnic gospodarczych regionu. Druga koncepcja polega natomiast na planowaniu rozwoju na podstawie badań i wskaźników oraz opinii ekspertów. Nie ma przeciwskazań, by obie koncepcje były używane jednocześnie. Warto monitorować postępy w rozwoju regionów konkurencyjnych oraz sposoby osiągania przewagi konkurencyjnej. Jednocześnie istotne jest konsultowanie wyników $\mathrm{z}$ ekspertami oraz poleganie na ocenie wskaźników wewnętrznych regionu, a także porównywanie ich ze wskaźnikami regionów konkurencyjnych.

Oprócz schematów, istnieje także kilka konkretnych metod tworzenia strategii rozwoju regionalnego i lokalnego. Wśród nich występują: metoda konferencji poszukiwawczych, biznesplanu, społeczno-ekspercka, strukturalna, scenariuszy, polityczna ${ }^{4}$. Nie są to wszystkie dostępne metody, a najważniejsze jest ich elastyczne stosowanie, dopasowane do potrzeb obszaru, co jest obowiązkiem władz.

Strategia nie jest jedynym instrumentem wykorzystywanym w zarządzaniu rozwojem regionalnym i lokalnym. Oprócz niej istnieją także plany jednorazowe lub ciągłe, które mają za zadanie realizować przedsięwzięcia strategii. Plany można także podzielić na operacyjne i strategiczne, przy czym pierwsze są bardziej konkretne - dotyczą jednego zadania oraz są nastawione na konkretne wyniki, a drugie mają charakter twórczy, ale dotyczą jednego głównego aspektu rozwoju. Strategia rozwoju regionalnego i lokalnego powinna zawierać takie plany funkcjonalne, jak: strategia rozwoju społecznego, gospodarczego, strategia rozwoju administracji publicznej, strategia

2 J. Adamiak, Samorząd terytorialny w systemie władzy publicznej, [w:] Kosiedowski W. (red.), Samorzad Terytorialny $w$ procesie rozwoju regionalnego i lokalnego, Dom Organizatora, Torun 2005, s. 99.

${ }^{3}$ Tamże, s. 99.

${ }^{4}$ Tamże, s. 100. 
budowania pozycji rynkowej. Dopiero później należy uwzględniać działania kierunkowe na poszczególne elementy potencjału. Liczba planów funkcjonalnych, wpływających na tworzenie strategii, to kolejny aspekt złożoności rozwoju regionalnego oraz dowód na to jak wiele elementów należy brać pod uwagę przy tworzeniu strategii. Można na tej podstawie wywnioskować, iż tworzenie, realizacja oraz monitorowanie strategii są procesami długotrwałymi.

Istnieje kilka zasad, które wpływają na jakość i aplikacyjność strategii ${ }^{6}$. Zasady organizacyjne polegają na współpracy instytucji dla trwałego charakteru tworzenia strategii i jej wdrażania, przy ciągłej współpracy stron. Zasady analityczne polegają na ocenie roli jaką pełni region $\mathrm{w}$ gospodarce oraz dostosowaniu strategii do zastałej sytuacji, a zasady wdrożeniowe to wdrażanie strategii poprzez procedury zarządzania projektami, ze szczególną uwagą zwróconą na innowacyjność oraz tworzenie nowych struktur organizacyjnych.

Strategia pełni kilka funkcji, a wśród nich: formułowanie wewnątrzregionalnych celów rozwoju, optymalizacja lokalnych celów rozwoju, osiąganie porozumienia dla ponadregionalnych celów rozwoju, identyfikacja regionalnych uwarunkowań oraz oddziaływanie na politykę przestrzenną państwa, wskazywanie podstaw planistycznych dla przedsięwzięć centralnych ${ }^{7}$. Cele te podsumowują rolę, jaką strategia odgrywa $\mathrm{w}$ zarządzaniu rozwojem regionalnym i lokalnym, a mianowicie doprowadza strony do konsensusu w wyznaczaniu celów dla dobra wspólnego mieszkańców regionu.

Ważnym elementem ujętym w strategii rozwoju regionalnego i lokalnego jest planowanie przestrzenne. Integracja planowania przestrzennego i regionalnego ma znaczny wpływ na zarządzanie rozwojem. Przestrzeń jest ograniczona, stąd konieczność jej przezornego planowania jest taka ważna. Wraz z większą liczbą ludności zamieszkującą dany obszar, sposoby jego zagospodarowania intensyfikują się. Przestrzeń stawia opór im dalej jest położona oraz im mniej rozbudowany system komunikacji prowadzący do tego miejsca. Stąd więcej energii i czasu trzeba, by dotrzeć i zagospodarować regiony peryferyjne. Co więcej, przestrzeń jest zróżnicowana pod względem tego jak stworzyła ją natura oraz jak przekształcił ją

\footnotetext{
5 J. Strojny, Model zarządzania strategicznego rozwojem lokalny, [w:] Plawgo B. (red.), Polska Wschodnia - zarzadzanie rozwojem, Wyższa Szkoła Administracji Publicznej im. Stanisława Staszica, Białystok 2008, s. 314.

${ }^{6}$ K. Heffner, Strategie rozwoju regionalnego i lokalnego, [w:] Kosiedowski W. (red.), Gospodarka regionalna i lokalna, PWN, Warszawa 2008, s. 159.

${ }^{7}$ Tamże, s. 164.
} 
człowiek $^{8}$. Podczas kształtowania tak różnej przestrzeni bardzo ważne jest takie jej planowanie, które nie kończy się wraz z granicami państwa, czy regionu. Planowanie przestrzenne powinno mieć samo w sobie wymiar ponadregionalny oraz wymagać szerszego zasięgu współpracy, by być efektywnie organizowane i koordynowane. Takie przedsięwzięcie wymusza powstanie wielu działań, m.in. takich, które mają na celu uzyskanie informacji o danych regionalnych. W związku $\mathrm{z}$ tym elementy planowania przestrzennego powinny być ujęte w strategii rozwoju regionalnego i lokalnego.

\section{Podmioty odpowiedzialne za strategie rozwoju}

Przygotowanie, wdrażanie i monitorowanie wykonania strategii należy do władz samorządowych. Przygotowanie strategii rozwoju województwa należy do samorządu województwa. Do władz centralnych należy przygotowanie ogólnych dokumentów krajowych, do których odnosić się będą strategie regionalne i lokalne. Co więcej, strategie rozwoju regionalnego i lokalnego muszą powstawać w oparciu o Strategię Lizbońską, a obecnie o zastępujący ją dokument „EUROPA 2020”. Cele zawarte w dokumentach unijnych powinny być wzięte pod uwagę $\mathrm{w}$ tworzeniu strategii regionalnej ilokalnej. Warto również tworzyć strategie w oparciu o kryteria tworzenia strategii obowiązujące w Unii Europejskiej, z racji możliwości pozyskania środków na jej realizację. Jeśli strategia była wzorowana na unijnych wymogach, pozyskanie dofinansowania jest o wiele bardziej realne.

Strategia zakłada ogólnikowe cele, a nie konkretne zadania i sposoby ich rozwiązania. Formą konkretyzacji strategii są programy rozwoju (krajowe i regionalne programy operacyjne oraz wojewódzkie i wieloletnie programy rozwoju). Programy powinny być tworzone $\mathrm{w}$ regionach przez regiony, by lepiej odpowiadały ich potrzebom.

Inicjatorem przygotowywania strategii jest zarząd województwa, a samorząd województwa odpowiada za określenie i realizację strategii. Zarząd ma za zadanie przygotowanie projektów strategii rozwoju województwa, planu zagospodarowania przestrzennego i regionalnych programów operacyjnych oraz ich wykonywanie. Po ich przygotowaniu, zarząd wnioskuje o podjęcie odpowiedniej uchwały przez sejmik. Od sejmiku zależy opracowanie

\footnotetext{
${ }^{8}$ M. Borsa, Polityka przestrzenna w gospodarce regionalnej i lokalnej, [w:] Strzelecki Z. (red.), Gospodarka regionalna i lokalna, PWN, Warszawa 2008, s. 196.
} 
zasad, trybu i harmonogramu opracowania strategii rozwoju (zadania organów samorządu oraz tryb i zasady współpracy). Jedynie sejmik ma wyłączność na uchwalenie strategii i planu zagospodarowania przestrzennego ${ }^{9}$. Wojewódzka strategia rozwoju nie może być sumą strategii gminnych i powiatowych ${ }^{10}$, ale może uwzględniać ich interesy.

Tworzenie strategii regionalnych i lokalnych jedynie na podstawie dokumentów centralnych (krajowych i unijnych), samodzielnie przez samorządy regionalne, prowadzi do regionalnego, a nie centralnego planowania rozwoju w regionach. Samorządom wojewódzkim zostało również powierzone tworzenie i zarządzanie programem operacyjnym województwa. Sprowadzenie planowania do szczebla regionalnego ma na celu jego większą efektywność. Regiony są w stanie lepiej określić swoje mocne i słabe strony oraz potrzeby, $\mathrm{z}$ racji bliskości problemów. Mogą prowadzić bezpośredni dialog z mieszkańcami regionu, by określić w którą stronę powinien on się rozwijać. Region jest bliżej oraz ma stosunkowo mniejszą przestrzeń do zarządzania.W oparciu o strategie rozwoju województwa, samorząd województwa tworzy wiele planów działań, na przykład zwiększających zatrudnienie, czy ochrony środowiska.

\section{Strategia Rozwoju Województwa Podlaskiego}

Strategia Rozwoju Województwa Podlaskiego (SRWP) jest podstawowym dokumentem strategicznym Samorządu Województwa Podlaskiego, określającym cele i kierunki rozwoju regionu. 30. stycznia 2006 r. Sejmik Województwa Podlaskiego przyjął uchwałę w sprawie aktualizacji SRWP. Horyzont czasowy dokumentu dotyczy 2020 r., podczas, gdy poprzednia strategia sięgała 2010r. Konieczność aktualizacji wynikała z zastąpienia ZPORR 16 RPO, uwzględnienia spójności terytorialnej, uwzględnienia Strategii Lizbońskiej, zwielokrotnionych środków na lata 2007-2013 oraz nowych statystyk ${ }^{11}$. SRWP określa misję rozwoju województwa i cele, przyporządkowując im priorytety. W dokumencie wymienione są, przykładowo, wiodące klastry oraz płaszczyzny współpracy

\footnotetext{
${ }^{9}$ K. Wlaźlak, Rozwój regionalny jako zadanie administracji publicznej, op. cit., s. 270.

${ }^{10}$ Tamże, s. 271.

${ }^{11}$ Raport z przebiegu prac nad dokumentem Strategii Rozwoju Województwa Podlaskiego do 2020 roku i zgłoszonymi do niego uwagami, www.wrotapodlasia.pl, dostęp na 21.05.2012.
} 
regionalnej, a także wszelkie inne aspekty rozwoju wraz z diagnozą stanu wyjściowego regionu. Realizacja Strategii przyczynia się do zwiększenia spójności społeczno-ekonomicznej i konkurencyjności regionu poprzez stworzenie warunków do lepszego wykorzystania jego potencjału. Strategia nie zawiera szczegółowych rozstrzygnięć w sprawie konkretnych projektów i działań w określonym czasie i miejscu. Rozstrzygnięcia takie są zawarte w programach wojewódzkich i operacyjnych.

Misja, z której wynika powołanie Strategii, brzmi: „Województwo podlaskie regionem aktywnego i zrównoważonego rozwoju $\mathrm{z}$ wykorzystaniem walorów środowiska naturalnego, wielokulturowej tradycji i położenia przygranicznego"12. Misja zawiera także ideę zrównoważonego rozwoju, promowaną przez Strategię Lizbońską. Elementem strategii jest także diagnoza województwa oraz analiza SWOT. Wśród silnych stron wymieniono przede wszystkim położenie przygraniczne, pobudzające współpracę transgraniczną oraz umacnianie aglomeracji białostockiej. Wśród słabych stron - niski poziom dochodów i inwestycji oraz słabo rozwiniętą infrastrukturę transportową. Wśród szans - dostępność transportową poprzez I Paneuropejski Korytarz Transportowy. Wśród zagrożeń - większą konkurencyjność sąsiednich regionów. Wyżej wymienione elementy były niezbędne do sformułowania kolejnego elementu strategii, czyli celów strategicznych.

Cele strategiczne oparte są na słabych i mocnych stronach regionu. Mają one za zadanie przedstawić wizję rozwoju regionu w jak najbardziej efektywny, ale możliwy do osiągnięcia sposób. W następnej kolejności poszczególnym celom przyporządkowane są priorytety i działania. Wśród siedmiu celów strategicznych wymienione zostały: podniesienie atrakcyjności inwestycyjnej województwa, rozwój zasobów ludzkich zgodnie z potrzebami rynku pracy, podniesienie konkurencyjności podlaskich firm $\mathrm{w}$ aspekcie krajowym i międzynarodowym, ochrona środowiska naturalnego, rozwój turystyki $\mathrm{z}$ wykorzystaniem walorów przyrodniczych idziedzictwa kulturowego, wykorzystanie transgranicznego i przygranicznego położenia województwa, rozwój rolnictwa i tworzenie warunków wielofunkcyjnego rozwoju wsi. Każdy z celów porusza inny aspekt rozwoju województwa, a szczególnie te, w których dzięki analizom zidentyfikowano zacofanie w rozwoju.

12 Załącznik do Uchwały $\mathrm{Nr}$ XXXV/438/06 Sejmiku Województwa Podlaskiego z dnia 30 stycznia 2006 r., Strategia Rozwoju Województwa Podlaskiego do 2020 roku, Białystok 2006, s. 33. 
Kolejnym elementem zawartym w Strategii są płaszczyzny współpracy województwa oraz synteza planowania przestrzennego. Następnie w Strategii uwzględnione zostały instrumenty realizacji SRWP oraz sposoby monitorowania (poprzez wskaźniki). Wśród instrumentów realizacji, głównie finansowych, wymienionych w strategii są głównie środki zewnętrzne.

Instrumenty finansowe ujęte w SRWP to, m.in.: publiczne środki wspólnotowe (Europejski Fundusz Rozwoju Regionalnego, Fundusz Spójności, Europejski Bank Inwestycyjny), inna publiczna, pomoc ze środków zagranicznych, publiczne środki krajowe, wkład własny beneficjentów ${ }^{13}$.

SRWP, pomimo aktualizacji, została oceniona dość krytycznie. Największe zarzuty jej stawiane dotyczyły nietrafnie sformułowanych celów i zbyt ogólnych sformułowań w działaniach ${ }^{14}$. Przed pierwszą aktualizacją Strategia miała 6 priorytetów i aż 103 cele. Brakowało informacji o autorach oraz szczegółowych pozycji dotyczących monitorowania ${ }^{15}$.

Jednym z dowodów na efektywność realizacji Strategii jest jej powiązanie $\mathrm{z}$ regionalnym programem operacyjnym województwa podlaskiego oraz zwiększające się środki na jej realizację. Strategia była wykorzystywana do formułowania celu głównego oraz celów szczegółowych programu. Jego cele szczegółowe skupiały się na podniesieniu atrakcyjności inwestycyjnej i turystycznej województwa, konkurencyjności podlaskich firm oraz rozwoju zasobów ludzkich zgodnie z potrzebami rynku pracy ${ }^{16}$. Można łatwo zauważyć, że te cele pokrywają się z celami Strategii całkowicie. Będą one realizowane $\mathrm{w}$ ramach programu poprzez ingerencję $\mathrm{w}$ infrastrukturę techniczną, społeczną i bazę ekonomiczną województwa.

Strategia jest ściśle powiązana także z innymi dokumentami, które mogą wymuszać na niej aktualizacje. Jednym z problematycznych aspektów strategii rozwoju województw jest ich okres planowania. Dla SRWP kończy się on w 2020 r. (data

13 Tamże, s. 64.

14 L. Kupiec, Strategia rozwoju województwa podlaskiego do 2020 r., www.mrr.gov.pl/rozwoj_regionalny/poziom_regionalny/strategia_rozwoju_p olski_wschodniej_do_2020/dokumenty/Documents/0b3709814cff4877a7f2f2 3ad3fa2745Kupiec.pdf, dostęp na 20.04.2012.

${ }^{15}$ G. Gorzelak, B. Jałowiecki, Strategie rozwoju regionalnego województw: próba oceny, ,Studia regionalne i lokalne”, nr 1(5)/2001, s. 10.

16 Regionalny Program Operacyjny Województwa Podlaskiego, www.rpowp.wrotapodlasia.pl/private/upload/file/edfa14bf03eb6377a0ed4d47 396b17c0.pdf, dostęp na 25.05.2012. 
opublikowania dokumentu to 2006 r.). Okres planowania jest zatem dość długi. W przypadku strategii innych województw okresy są różne, co jest dość problematyczne, szczególnie ze względu na dopasowanie do innych dokumentów, czy zwykłe porównanie realizacji strategii różnych regionów.

Realizacja Strategii oraz jej monitoring są bardzo ważnymi etapami. Należy do tego pamiętać o ciągłym szkoleniu pracowników oraz zwykłym rozpowszechnianiu strategii wśród mieszkańców. Strategia jest ogólnodostępna na stronach internetowych oraz w urzędach. Rozpowszechnianie wiedzy o Strategii odbywa się w ramach szkoleń, wykładów i konferencji. Świadomość mieszkańców o istnieniu Strategii pozwola na wgląd w kierunki rozwoju regionu, co wpływa bezpośrednio także na ich życie.

24 października 2011 r. sejmik województwa podlaskiego przyjął uchwałę $\mathrm{W}$ sprawie drugiej aktualizacji SRWP oraz Regionalnej Strategii Innowacji Województwa Podlaskiego (RSIWP), związanej głównie z rozpoczynającym się nowym okresem planowania 2014-2020. W uchwale zauważa się kilka dokumentów, mających wpływ na aktualizację dokumentu, a wśród nich: Krajową Strategię Rozwoju Regionalnego 2010-2020: Regiony, Miasta, Obszary Wiejskie (z dn. 13.07.2010); Strategię Rozwoju SpołecznoGospodarczego Polski Wschodniej do roku 2020; Średniookresową Strategię Rozwoju Kraju i Długookresową Strategię Rozwoju Kraju (pierwsza perspektywie 2030r., druga - 2020r. zastępująca obecną Strategię Rozwoju Kraju 2007-2015, obie w przygotowaniu) oraz strategie zintegrowane. Co więcej, SRWP będzie miała na uwadze dokument, który zastąpił Strategię Lizbońską - „EUROPA 2020. Strategia na rzecz inteligentnego i zrównoważonego rozwoju sprzyjającego włączeniu społecznemu oraz pakiet rozwiązań, związanych $\mathrm{z}$ uruchomieniem nowych wieloletnich ram finansowych w perspektywie 2014-2020".

Projekt drugiej aktualizacji zostanie przedstawiony w listopadzie 2012 r, a gotowa SRWP powinna zostać przyjęta przez sejmik województwa we wrześniu 2013 r. W miesiącach od lipca do października 2012 r. odbywały się spotkania konsultacyjne w największych miastach województwa: Białymstoku, Łomży, Siemiatyczach i Suwałkach (rysunek 1). Podczas spotkań, w których oprócz ekspertów brali udział również mieszkańcy województwa, najczęściej wymienianymi obszarami wsparcia, na które liczy społeczeństwo były: wykorzystanie odnawialnych źródeł energii, wykorzystanie przygranicznego położenia, środowiska naturalnego oraz rozbudowa infrastruktury transportowej, baza surowców rolno- 
spożywczych, wizerunek ekologicznego Podlasia, podnoszenie kreatywności i innowacyjności firm ${ }^{17}$. Obszar powtarzający się wśród odpowiedzi we wszystkim miastach to przygraniczne położenie województwa podlaskiego. Umożliwia ono nie tylko rozwój regionalny oparty na współpracy transgranicznej, lecz również możliwość pozyskania dodatkowych środków na programy tej współpracy z UE. Województwo posiada wspólne granice z Litwą oraz dwoma państwami spoza UE: Rosją i Białorusią, co umożliwia finansowanie w ramach Programu Współpracy Transgranicznej, Europejskiej Współpracy Terytorialnej oraz Europejskiego Instrumentu Sąsiedztwa i Partnerstwa.

\section{Rysunek 1. Harmonogram prac nad drugą aktualizacją SRWP}

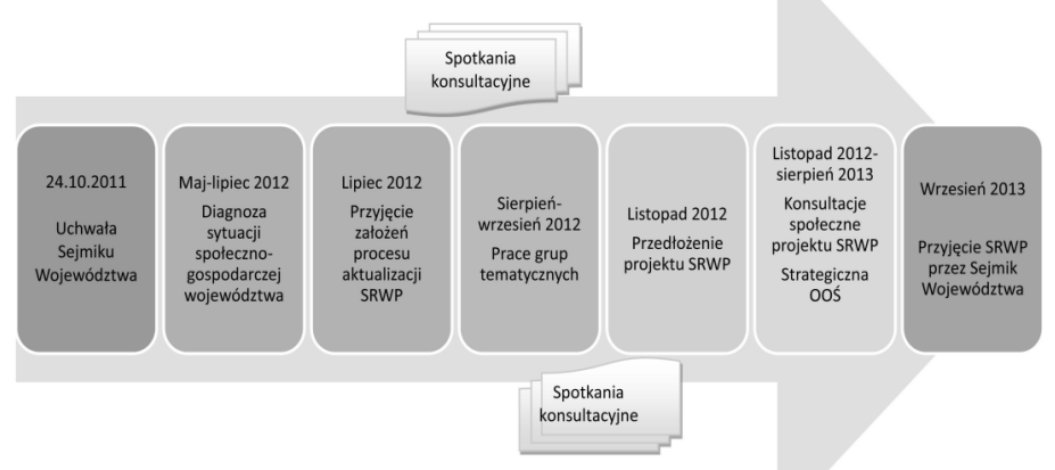

Źródło: www.strategia.wrotapodlasia.pl/pl/Terminy, stan na 02.11.2012.

Problemem strategii jest to, iż $\mathrm{w}$ jej trzeciej wersji (drugiej aktualizacji), podobnie jak w obu poprzednich, wśród słabych stron wymienione zostały te same obszary, czyli: słaba infrastruktura transportowa, niska konkurencyjność i innowacyjność gospodarki, nadmierna emigracja ludności, czy niski poziom $\mathrm{PKB}^{18}$. Może to

17 www.strategia.wrotapodlasia.pl/pl/Aktulanosci/g_os_om__w_deba_o. htm, dostęp na 03.11.2012, www.strategia.wrotapodlasia.pl/pl/Aktulanosci/ w_deba_czas_na_suwa. htm, dostęp na 03.11.2012, www.strategia. wrotapodlasia.pl/pl/Aktulanosci/w_siem_o_rozw_woje_ab8c846d521c8.htm, dostęp na 03.11.2012.

18 Załącznik do Uchwały $\mathrm{Nr}$ XXXV/438/06 Sejmiku Województwa Podlaskiego z dnia 30 stycznia 2006 r., op. cit., s. 33; Strategia rozwoju 
świadczyć o nieefektywności strategii, która istnieje już długi czas (SRWP do roku 2010 powstała w 2003 r.).

W uchwale $\mathrm{w}$ sprawie drugiej aktualizacji przyjęto także aktualizację RSIWP. Wzrost wagi tego dokumentu po 2013 r. oraz stopień zintegrowania tego dokumentu z SRWP sprawił, iż strategia innowacji będzie stanowiła załącznik do zaktualizowanej SRWP. Uchwała przedstawia także zasadność potrzeby aktualizacji, która wynika ze zmiany sytuacji społeczno-gospodarczej oraz zmiany okresów programowania Unii Europejskiej.

\section{Podsumowanie}

Strategia rozwoju regionalnego i lokalnego zapobiega przede wszystkim rozbieżnościom w kierunkach planowania. Gdyby każda jednostka w różny sposób odpowiedzialna za rozwój regionu działała bez wymiany informacji, nie osiągnęłaby efektów tak dobrych jak ze strategią. Doświadczenie organizacji w stosowaniu strategii zachęciło jednostki samorządu terytorialnego do wdrażania własnych, wzorowanych na tych $\mathrm{w}$ organizacjach. Pomysł ten pojawił się na szerszą skalę w czasie akcesji Polski do Unii Europejskiej. W ramach dobrych praktyk regiony Polski nauczyły się programować swój rozwój, który zmierzał w stronę decentralizacji. Obecnie zarządzanie rozwojem w Polsce polega na posiadaniu strategii rozwoju województwa przez wszystkie województwa, a także strategii rozwoju gmin lub powiatów przez sporą część gmin lub powiatów. Strategia rozwoju województwa podlaskiego jest przykładowym instrumentem, który dalekosiężnie dotyczy już 2020 r. Pomimo swoich wad efektywnie steruje rozwojem regionalnym na Podlasiu, a także wyznacza ramy odniesienia dla innych dokumentów.

Okres planowania 2014-2020 jest prawdopodobnie ostatnim, który zaoferuje województwu podlaskiemu dużą ilość środków na realizację strategii. Właśnie wtedy SRWP zostanie oceniona pod kątem sfinansowania budżetu. Środki z UE są kluczowe dla istnienia strategii oraz efektów, jakie osiągnie. Istotne jest również, by nowa strategia na ten okres wzięła pod uwagę mocne i słabe strony województwa, a w szczególności jego przygraniczne położenie oraz słabą infrastrukturę transportową. Polityka regionalna UE zdaje się traktować wschodnie regiony jako realizatorów współpracy ze Wschodem. Następuje powolna decentralizacja w tym obszarze.

województwa podlaskiego do roku 2010, www.strategia.wrotapodlasia.pl/pl/ strategia/o_strategii.htm, dostęp na 03.11.2012. 
Regiony wschodnie, w tym województwo podlaskie, są relatywnie słabiej rozwinięte. UE we współpracy ze Wschodem widzi czynnik rozwoju regionalnego.

Nie należy w SRWP upatrywać skoku cywilizacyjnego w postaci zrównania rozwoju regionalnego $\mathrm{z}$ poziomem, jaki odnotowuje się, np. w województwie mazowieckim, lecz zmian długoterminowych, ukierunkowanych $\mathrm{w}$ stronę poprawienia warunków życia w województwie. SRWP spełniła swoją rolę $w$ okresie planowania 2007-2013, co można stwierdzić na podstawie środków finansowych z UE, jakie zostały wykorzystane na realizację celów ujętych w strategii, zwiększenia tych środków w okresie planowania 2007-2013, a także na podstawie faktu, iż nie jest tworzona nowa strategia, ale tylko jej aktualizacja. Słabą stroną realizacji strategii jest to, iż mimo jej trzeciej wersji, słabe strony i zagrożenia są wciąż upatrywane w tych samych obszarach, co może świadczyć o nieefektywnym jej wdrażaniu. Strategie rozwoju są potrzebne w zarządzaniu rozwojem regionalnym, by możliwe było określenie miejsca w jakim znajduje się region, co dotychczas udało się zrobić, wskazanie jakie popełniono błędy oraz jakie są oczekiwania w następnych latach.

\section{Bibliografia}

1. Adamiak J., Samorząd terytorialny w systemie władzy publicznej, [w:] Kosiedowski W. (red.), Samorzad Terytorialny w procesie rozwoju regionalnego i lokalnego, Dom Organizatora, Toruń 2005.

2. Borsa M., Polityka przestrzenna w gospodarce regionalnej i lokalnej, [w:] Strzelecki Z. (red.), Gospodarka regionalna i lokalna, PWN, Warszawa 2008.

3. Gorzelak G., Jałowiecki B., Strategie rozwoju regionalnego województw: próba oceny, „Studia regionalne i lokalne”, nr $1(5) / 2001$.

4. Heffner K., Strategie rozwoju regionalnego i lokalnego, [w:] Kosiedowski W. (red.), Gospodarka regionalna i lokalna, PWN, Warszawa 2008.

5. Kupiec L., Strategia rozwoju województwa podlaskiego do roku 2020, www.mrr.gov.pl/rozwoj_regionalny/poziom_regionalny/ strategia_rozwoju_polski_wschodniej_do_2020/dokumenty/Docu ments/0b3709814cff4877a7f2f23ad3fa2745Kupiec.pdf.

6. Strojny J., Model zarządzania strategicznego rozwojem lokalny, [w:] Plawgo B. (red.), Polska Wschodnia-zarządzanie rozwojem, 
Wyższa Szkoła Administracji Publicznej im. Stanisława Staszica, Białystok 2008.

7. Wlaźlak K., Rozwój regionalny jako zadanie administracji publicznej, Wolters Kluwer, Warszawa 2010.

8. Raport $\mathrm{z}$ przebiegu prac nad dokumentem Strategii Rozwoju Województwa Podlaskiego do 2020 roku i zgłoszonymi do niego uwagami, www.wrotapodlasia.pl.

9. Regionalny Program Operacyjny Województwa Podlaskiego na lata 2007-2013, www.rpowp.wrotapodlasia.pl/private/upload/file/ edfa14bf03eb6377a0ed4d47396b17c0.pdf.

10. Strategia rozwoju województwa podlaskiego do roku 2010, www.strategia.wrotapodlasia.pl/pl/strategia/o_strategii.htm.

11. Załącznik do Uchwały Nr XXXV/438/06 Sejmiku Województwa Podlaskiego z dnia 30 stycznia 2006 r., Strategia Rozwoju Województwa Podlaskiego do 2020 roku, Białystok 2006.

\section{Strony internetowe}

1. www.strategia.wrotapodlasia.pl.

\section{Streszczenie}

Zarządzanie było niegdyś skupione na zarządzaniu organizacjami. Ostatnio jednak, że rzeczywistość zmieniła się i zarządzanie stało się kwestią polityki regionalnej. Rozwój regionalny jest procesem bardzo złożonym i strategie rozwoju wydają się być niezastąpione w zarządzaniu ich rozwojem. Podmioty odpowiedzialne za realizację strategii w Polsce to władze lokalne. Przykładem strategii omawianej $\mathrm{W}$ artykule jest Strategia Rozwoju Województwa Podlaskiego. Jest to jedna ze strategii sięgająca 2020r. $\mathrm{W}$ artykule mówiona jest struktura strategii rozwoju na podstawie tego przykładowego dokumentu. Strategia jest obecnie aktualizowana z powodu nowych ram finansowych na lata 2014-2020. Zarówno eksperci, jak i mieszkańcy uczestniczą w tworzeniu tego dokumentu.

\section{Summary}

\section{DEVELOPMENT STRATEGY AS A TOOL OF THE MANAGEMENT OF REGIONAL AND LOCAL DEVELOPMENT}

Management used to be oriented on organizations mainly. However, recently that reality has changed and management has become an issue of regional policy. Regional development is a very complex process and development strategies appeared to be irreplaceable in managing their development. Entities responsible for the implementation of the strategies in Poland are local authorities. An example of such a strategy is the 
Development Strategy of Podlaskie Voivodeship. It is one of the strategies which reaches the year 2020. In the article the structure of development strategies is described on the basis of that example strategy. The strategy is now being actualized because of the new financial framework 2014-2020. Both, experts and the residents take part in the creation of the document. 